\title{
Donor Fragmentation and Bureaucratic Quality in Aid Recipients
}

\author{
Stephen Knack*
}

Aminur Rahman**

\begin{abstract}
World Bank Policy Research Working Paper 3186, January 2004
The Policy Research Working Paper Series disseminates the findings of work in progress to encourage the exchange of ideas about development issues. An objective of the series is to get the findings out quickly, even if the presentations are less than fully polished. The papers carry the names of the authors and should be cited accordingly. The findings, interpretations, and conclusions expressed in this paper are entirely those of the authors. They do not necessarily represent the view of the World Bank, its Executive Directors, or the countries they represent. Policy Research Working Papers are available online at http://econ.worldbank.org.
\end{abstract}

*Address correspondence to Stephen Knack, Senior Research Economist, World Bank, 1818 H St. NW, Washington DC 20433. Email: sknack@,worldbank.org. phone: 202-458-9712. fax: 202-522-1154.

**Economics Department, University College London, Gower Street, London WC1E 6BT. Email: rahman.aminur@ucl.ac.uk.

This paper was funded as background work for the 2004 World Development Report. The authors are grateful to Virginia Yee for information on and assistance with the AiDA data base, to Claudio Montenegro and Denis Nikitin for assistance with the OECD-DAC aid data, and to Ritva Reinikka, Omar Azfar, Bertin Martens, Poul Engberg-Pedersen and Bill Shaw for valuable discussions and comments. 


\begin{abstract}
This paper analyzes the impact of donor fragmentation on the quality of government bureaucracy in aid recipient nations. A formal model of a donor's decision to hire government administrators to manage donor-funded projects predicts that the number of administrators hired declines as the donor's share of other projects in the country increases, and as the donor's "altruism" (concern for the success of other donors' projects) increases. These hypotheses are supported by cross-country empirical tests, using an index of bureaucratic quality available for aid recipient nations over the 19822001 period. Declines in bureaucratic quality are associated with higher donor fragmentation (reflecting the presence of many donors, each with a small share of aid), and with smaller shares of aid coming from multilateral agencies, a proxy for donor "altruism."
\end{abstract}


'tis folly in one Nation to look for disinterested favors from another- that it must pay with a portion of its Independence for whatever it may accept under that character... -from George Washington's "Farewell Address" (1796)

\section{Introduction}

The success of Marshall Plan aid, relative to aid to less developed countries more recently, is partly attributable to differences between the groups of recipients. Western Europe had huge advantages in putting aid to effective use. Unlike most aid recipients of subsequent decades, it had skilled labor, experienced managers and entrepreneurs, and a history of reasonably effective financial and judicial systems and public administrations (Degnbol-Martinussen and Engberg-Pedersen 2003: 288). However, differences on the donor side also may have contributed to the Marshall Plan's greater success. Marshall Plan recipients had to deal only with a single donor, in contrast to the dozens of bilateral and multilateral agencies and hundreds of NGOs in the aid business today. Also, Marshall Plan aid, "history's most successful structural adjustment program" (De Long and Eichengreen 1993), was not disbursed in the form of hundreds of separate donormanaged projects in each recipient nation. ${ }^{1}$ Aid success stories in Taiwan, Botswana and Korea have also been attributed in part to the presence of a single or dominant donor (Brautigam 2000; Azam, Devarajan, and O'Connell 2002).

In contrast, recent recipients of development assistance interact with dozens of donors. The median number of official donors in recipient countries in 2000 was 23 (Acharya et al. 2003). Morss (1984) reports that the UNDP Resident Representative in Lesotho in 1981 counted 61 separate donors financing 321 projects, in a country of only about 1.4 million people. In 2002, there were 25 official bilateral donors, 19 official multilateral donors, and about 350 international NGOS operating in Vietnam-where aid as a share of GDP is actually lower than in most of Africa - accounting for over 8,000 development projects (Acharya et al. 2003). In the typical African country, aid is provided by "some thirty official donors in addition to several dozen international NGOs...through over a thousand distinct projects and several hundred resident foreign experts" (van de Walle 1991: 58). Thousands of quarterly project reports are submitted to multiple oversight agencies. Hundreds of missions monitor and evaluate these projects and programs annually in many recipients, and each mission expects to meet with key government officials and to obtain comments from officials on its reports (van de Walle and Johnston 1996).

\footnotetext{
${ }^{1}$ In her foreword to Kanbur and Sandler (1999), Nancy Birdsall writes: "The Marshall Plan worked because there was one donor, the U.S., and the U.S. set up rules that ensured the Europeans would themselves take charge."
} 
Why might aid be more effective coming from a single or dominant donor? In a recipient with many donors, each of which is responsible for only a small part of development assistance, responsibility for success or failure is diffused, and any single donor will rarely have much of a stake in the country's economic and social development (Belton 2003). Aid involves a set of collective action problems when there are multiple donors, each concerned with development in the recipient country, but with their own national goals as well, that sometimes detract from development objectives. Donor countries all have their own commercial and security objectives, and their aid agencies additionally have the objective of maximizing aid budgets, which requires satisfying key domestic constituencies in parliament and among aid contractors and advocacy groups. This latter objective often requires making the results of aid programs visible, quantifiable, and directly attributable to the donor's activities - even when doing so reduces the developmental impact of aid. From the perspective of a recipient country's welfare, incentives for any one donor to shirk on activities that maximize overall development in favor of activities that contribute to donor-specific goals strengthen as the number of donors increases.

Because supplier cartels are typically created to raise the price of their products, donor coordination may be viewed as something inimical to the development of aid recipient countries. However, donors have a common interest in development, as well as their separate "private" goals, which lead to practices such as tying aid, hiring away key government staff to run their projects, etc. Collusion by suppliers in this setting often can imply reducing rather than increasing the "price" of aid, and some forms of competition among donors can increase its price. Admittedly, donor cooperation sometimes takes the form of imposing unwelcome policy conditions, although government resistance to them is typically motivated more by concern over the rent-reducing effects of these policies than by any concern over adverse effects on poor people's welfare.

Costs associated with a proliferation of donors can be grouped into two broad categories. Some costs are primarily of a short-term and reversible nature, "merely" wasting resources unnecessarily. For example, tying aid to the employment of donorcountry contractors has been estimated in an OECD study to reduce its real value by between 15 percent and 30 percent (Jepma 1991). Transactions costs associated with numerous and diverse donor rules and procedures for managing aid projects and programs, different languages and fiscal calendars, etc. (see Berg 1993: 81; UNDP 2003: 148) can also be viewed as detracting from aid's value. ${ }^{2}$ There is much duplication in "country analytic work" such as poverty assessments, public expenditure reviews,

\footnotetext{
${ }^{2}$ Untying aid and standardizing and coordinating donor procedures would not necessarily increase the real resources to recipients, however, as political support for aid in donor countries might drop in response.
} 
governance and investment climate assessments, and fiduciary analyses sponsored by donors (OECD 2003: ch. 2). Authors of these reports frequently are unaware of recent studies on the same topic in the same country funded by a different donor (Easterly 2003: $15)$.

The second category of costs is more insidious and long-lasting, involving donor practices that tend to undermine the quality of governance or retard the development of public sector capacity. A few examples of these practices include providing aid through projects rather than through budget support, bypassing central government units (for example, by the use of project implementation units), relying on expatriates instead of subsidizing "learning by doing" by hiring local staff, and funding investment projects that in the aggregate imply unrealistically high recurrent expenditures in future years. In the latter case, donors in effect treat the budget for recurrent expenditures as a common-pool resource (Brautigam 2000), producing a tragedy of the commons in which roads are built but not repaired, and schools are built but not staffed. Donors engage in these practices to increase the visibility of their efforts and the short-term appearance of success for their individual projects, at the expense of coherent policy making and capacity building in the recipient country's public sector (World Bank 1998: 84). It is well-known in the aid business that however successful a project appears on its own terms, it will have little or no sustained impact in a poor sector-policy environment, and where it is not integrated into other donor-funded or government projects (Easterly 2003: 7; Kanbur and Sandler 1999: 29). However, where there are numerous donors, any one of them would gain only a small share of the total benefits, in terms of project success, from efforts to improve administrative capacity in the country, which would in effect subsidize the success of other donors' projects.

The remainder of this paper examines in more detail another much-discussed practice of this sort, donor "poaching" of qualified local staff. Section 2 summarizes the related literature, including anecdotal evidence, and presents a simple formal model of poaching as a collective action problem among donors. Cross-country data for testing the model's predictions are described in section 3, with results reported in section 4. Results from these tests support the hypothesis that aid undermines the quality of the government bureaucracy more severely in recipient countries where aid is fragmented among more donors. Section 5 summarizes and briefly suggests a few possible solutions, but notes the political difficulties in implementing them.

\section{Poaching}

Because of donors' need to show tangible results for their projects, excessive recourse is made to expatriate experts, especially long-term advisers. To the extent 
donors must work with counterparts in the local bureaucracy, these same pressures commonly lead donors to pay salary supplements to the more talented local staff. This practice distorts incentives for civil servants to turn their attention away from their other responsibilities - even those with greater impact on development - and toward the donor's projects (Arndt 2000: 166-67). It also creates incentives for officials to protect and extend aid projects from which they benefit, regardless of their merit, and to help perpetuate the practice of spending aid funds in the form of independent projects rather than in the form of coordinated, sectorwide programs or budget support (Acharya et al. 2003). The distinction between purely private consulting work and quasi-official work associated with donor projects is often blurred (Cohen and Wheeler 1997a: 142).

Control of salary and manpower policy is eroded as donors hire local staff for 'their' projects or contract with them to meet donor needs. Dual salary and incentive structures undermine morale and commitment among public sector employees who are left out of donor-distributed assignments... This neglect or subversion of existing structures creates organizational confusion and contributes to the withering of government capacity (Berg 1997: 82). ${ }^{3}$

Examples in the aid literature come primarily from Sub-Saharan Africa:

In Niger, for instance, the majority of NGOs appear to be operated by moonlighting civil servants and ex-ministers of cabinet. In several cases, high-level officials left government to create NGOs in order to receive donor support that had once gone to the official's ministry (van de Walle 2001: 165).

Van de Walle and Johnston (1996) find that “...master's level staff in government earn a fifth of what they could earn working for one of Nairobi's international management consulting firms or the resident mission of a donor agency." In Mozambique, a cleaner's salary in the international agencies sector was roughly equal to that of a national director in the civil service (Fallon and Pereira da Silva 1994: 82). Within project implementation units, salary benefits are often supplemented with access to vehicles and foreign travel for locally recruited staff. Many middle and high-level African managers left the civil service to work directly for the aid agencies, lured by salaries often five to 10 times higher than in the public service. In the early 1990s, a World Bank project hired Kenyan advisors, mostly from other government ministries, into the Ministry of Agriculture and Livestock Development, at salaries of between $\$ 3,000$ and $\$ 6,000$ a month, compared with a total compensation package of

\footnotetext{
${ }^{3}$ See Cohen and Wheeler (1997b: 321) for more detailed discussion on the damaging effects of "topping up" of officials' salaries by donors.
} 
approximately $\$ 250$ available to a senior economist in the civil service (Wilson 1993: 493).

Many trainees from donor-funded training programs leave the public sector to work for aid agencies or NGOs, and the most talented, ambitious and best trained are the most likely to leave. One study found that of 20 Kenyan economists receiving Master's level training in a donor-funded capacity building project between 1977 and 1988, 15 worked for aid agencies or NGOs directly, or for their projects by 1994. The study's authors concluded that "elite external Master's degrees are, in effect, passports out of the public sector" (Cohen and Wheeler 1997b: 312).

These problems are particularly severe where donors' presence is large and skilled labor is extremely scarce. In Mozambique, Fallon and da Silva (1994: 95) report that in a labor force of 6.2 million, fewer than 2,500 had university degrees, and only 20 had doctorates.

A World Bank (1998: 88) report laments the fact that donors "unwittingly" raid the civil service of its best and brightest to run their projects. However, this and other donor practices with potentially damaging effects are widely acknowledged by the donor agencies themselves (World Bank 2000: 20; 2003: ch. 11; UNDP 2003: ch. 8). The problem is donor incentives, not lack of awareness. Fallon and da Silva (1994: 98) report that in Mozambique, one of the most aid-intensive countries:

Donor-driven competition for skilled personnel is creating immense problems for government. The preoccupation of many donors with ensuring that their local administrations have a full complement of qualified staff and with securing, at all costs, the manpower required to implement their projects is depriving the government of the capacity to effectively manage its administration.

Donors, in deciding whether to poach the better-qualified civil servants to run their own projects, treat the government bureaucracy as a common-pool resource. Where there are fewer donors, each with a larger share of projects adversely affected by deteriorating administrative capacity, the external costs of poaching may be sufficiently high for an individual donor to influence its decision. Even in this case, however, there may be principal-agent problems within a donor agency, as officials with primary responsibility for the success of a particular project may have an incentive to hire the best possible local staff at the expense of the agency's broader objectives in the country. ${ }^{4}$

\footnotetext{
${ }^{4}$ Examples of intra-agency aid coordination problems are described in Wuyts (1996: 743), Mosley and Eeckhout (2000: 141, 145), and Whittington and Calhoun (1988: 301). Also see OECD (2003: 108).
} 
In principal, aid recipient governments could act to reduce the inefficiencies associated with competitive donor practices. They could always refuse some aid, ${ }^{5}$ attempting to reduce the number of donors active in the country, or, at least, the number active in each sector. In practice, principal-agent problems within the recipient country, either between a government with short time horizons and its citizens, or between line ministries and central ministries (Wuyts 1996: 742; van de Walle 2001: 208), often reduce the government's ability and interest in curtailing donor activities that are destructive for the long-run development of the country overall. For political leaders without sufficiently lengthy time horizons, the short-term personal benefits of corruption and patronage practices often outweigh the long-term costs of subverting administrative capacity (and judicial systems); insecure leaders treat the rational-legal order essential for development as a common-pool resource (van de Walle 2001).

The model below focuses on collective action failures among donors. It abstracts from principal-agent or other collective action problems within the recipient government, and within individual donor agencies. These simplifying assumptions should not be viewed, however, as attributing weak administrative capacity in aid recipients entirely to collective action failures among the donors.

\section{The Model}

Assume there are $(N+1)$ donor-funded aid projects, sponsored by $D$ donors, where $(N+1) \geq D .{ }^{6}$ Both $(N+1)$ and $D$, as well as the distribution of projects among donors, are exogenously determined. ${ }^{7}$ Welfare in the recipient nation increases with the aggregate output of all projects. The output ${ }^{8}$ of a representative project $i, Q_{i}$, increases at a diminishing rate with the number of high-quality managers employed on the project, $M_{i}$, and with a pure public good input, the number of high-quality managers employed in the government, $M_{g}$. The total number of high-quality managers employed by donors and government, $M$, is assumed to be fixed except in the very long run, a reasonable assumption in many aid-intensive countries in Sub-Saharan Africa and elsewhere (Fallon and da Silva 1994: 99; Wilson 1993: 496). For simplicity, we assume that $M$ is sufficiently large that hiring decisions by donor $d \in D$ for project $i$ have no effect on

\footnotetext{
${ }^{5}$ Uganda's stated policy is to decline all offers of stand-alone donor projects (OECD 2003: 121). Eritrea also has a reputation for selectivity in accepting aid offers.

${ }^{6}$ For simplicity, joint projects funded by multiple donors are ruled out.

${ }^{7}$ Determinants may include recipient nations' poverty levels, colonial heritage, geographical proximity to donors, ideological affinity with donors, media interest and access, and cooperation with donor country diplomacy.

${ }^{8}$ Project output can be viewed as the probability of project success. Donors routinely evaluate the extent to which completed projects succeeded in attaining certain objectives.
} 
hiring by $d$ and $(D-1)$ donors on other projects $j$. That is, the government employs all high-quality managers not employed by donors, so donors effectively hire managers away from government and not from each other. Thus:

$$
M_{g}\left(M_{i}\right)=M-M_{i}-\sum_{j \neq i} M_{j} \text {, with } M_{g}>0, \frac{\partial M_{g}}{\partial M_{i}}=-1 \text {, and } \frac{\partial M_{j}}{\partial M_{i}}=0
$$

All high-quality managers are equally productive and earn $W^{D}$ if employed by donors and $W^{G}<W^{D}$ if employed by government. The production technology is identical for all projects:

$$
Q_{i}=f\left(M_{i}, M_{g}\left(M_{i}\right)\right), \text { with } f_{M_{i}}^{\prime}>0 \text { and } f_{M_{i}}^{\prime \prime}<0
$$

Denote the marginal product of $M_{g}, f_{M_{g}}^{\prime}=\gamma>0$. For simplicity, assume $\gamma$ is constant over all projects, although this assumption is relaxed below. When $d$ hires a manager away from government employment for project $i$, the output of project $i$ increases by $f_{M_{i}}^{\prime}-\gamma$, and the output of each other project $j$ falls by $\gamma$. The opportunity cost to the project of hiring a manager is $W^{D}$ and $\gamma$, but the sum of opportunity costs to all other projects is $\gamma N$, where $N$ is the number of projects other than project $i$. The level of the pure public good input, $M_{g}$, is determined by donors, who view qualified managers as a common-pool resource.

A donor with multiple projects will internalize a fraction of the costs external to project $i$ associated with its choice of $M_{i}$, depending on its share of other projects $j$. Define $S_{d}=\frac{N_{d}}{N}$, where $N_{d}$ is the number of projects, other than project $i$, funded by donor $d \in D$. Further define $A_{d}$ as an "altruism" parameter, with $0 \leq A_{d} \leq 1$, reflecting the weight donor $d$ places on the success of projects funded by the other $(D-1)$ donors, relative to its own projects. If $d$ values only the success of its own projects, $A_{d}=0$. If it values the success of all projects equally, regardless of who is funding them, $A_{d}=1$. In choosing $M_{i}$, the number of managers to hire for project $i$, donor $d$ maximizes the following value function:

$$
\underset{M_{i}}{\operatorname{Max}} \quad V_{i}^{d}=f\left(M_{i}, M_{g}\left(M_{i}\right)\right)-W^{D} M_{i}-\gamma M_{i} N_{d}-\gamma M_{i}\left(N-N_{d}\right) A_{d}
$$

Or, equivalently,

$$
\underset{M_{i}}{\operatorname{Max}} \quad V_{i}^{d}=f\left(M_{i}, M_{g}\left(M_{i}\right)\right)-W^{D} M_{i}-\gamma M_{i} N S_{d}-\gamma M_{i}\left(1-S_{d}\right) A_{d}
$$

The third term in 2.1 represents costs external to project $i$ of donor $d$ 's choice of $M_{i}$ that are borne by its other projects. The final term reflects $d$ 's valuation of the 
external costs borne by other donors' projects. Comparative statics are provided below for three cases, varying in the degree of altruism $A_{d}$.

\section{Case I: "Selfish" Donor}

Where $A_{d}=0$, donor $d$ cares only about the success of its own projects, and the final term in (2.1) drops out:

$$
\underset{M_{i}}{\operatorname{Max}} \quad V_{i}^{d}=f\left(M_{i}, M_{g}\left(M_{i}\right)\right)-W^{D} M_{i}-\gamma M_{i} N S_{d}
$$

The necessary first-order condition is:

$$
\frac{\partial f(\bullet)}{\partial M_{i}}+\frac{\partial f(\bullet)}{\partial M_{g}} \frac{\partial M_{g}}{\partial M_{i}}=W^{D}+\gamma N S_{d}
$$

Because the second term on the left-hand side is equal to $-\gamma$, this expression can be rewritten as:

$$
\frac{\partial f(\bullet)}{\partial M_{i}}=\gamma+W^{D}+\gamma N S_{d}
$$

The right-hand side can be interpreted as the marginal cost of hiring $M_{i}$, which increases with $\gamma, W^{D}, N$, and $S_{d}$. Because the marginal product is (by assumption) diminishing in $M_{i}$ implying that the lower is $M_{i}$ the higher is its marginal product the donor's optimal choice of $M_{i}, M_{i}^{*}$, is inversely related to $\gamma, W^{D}, N$, and $S_{d}$. The latter prediction is directly related to the discussion of donor fragmentation, and is the focus of the empirical tests presented in later sections of the paper.

\section{Case II: Fully “Altruistic” Donor}

Where $A_{d}=1$, donor $d$ cares equally about the success of its own projects and those funded by other donors, and (2.1) reduces to:

$$
\underset{M_{i}}{\operatorname{Max}} \quad V_{i}^{d}=f\left(M_{i}, M_{g}\left(M_{i}\right)\right)-W^{D} M_{i}-\gamma M_{i} N
$$

The necessary first-order condition is:

$$
\frac{\partial f(\bullet)}{\partial M_{i}}+\frac{\partial f(\bullet)}{\partial M_{g}} \frac{\partial M_{g}}{\partial M_{i}}=W^{D}+\gamma N
$$


or, equivalently:

$$
\frac{\partial f(\bullet)}{\partial M_{i}}=\gamma+W^{D}+\gamma N
$$

An altruistic donor fully internalizes the external cost on other donors' projects of its choice of $M_{i}$, regardless of the share of projects it sponsors. The donor's optimal choice of $M_{i}, M_{i}^{*}$, is inversely related to $\gamma, W^{D}$, and $N$, as in case I above, but is now independent of $S_{d}$. Because $\gamma N \geq$ is $\gamma N S_{d}$, the marginal product of $M_{i}$ is higher at $M_{i}^{*}$ when $A_{d}=1$ than when $A_{d}=0$, except in the special case where $S_{d}=1$. Therefore, in case I, where $A_{d}=0, M_{i}^{*}$ exceeds the socially optimal level of $M_{i}$, unless $S_{d}=1$. Optimality is ensured when either a single donor funds all projects in the country, or donors do not distinguish their own projects from other projects.

\section{Case III: Imperfect Altruism}

Where $0<A_{d}<1$, donor $d$ places a positive weight on the success of other donor's projects, but places a greater weight on its own projects. From (2.1) the necessary first-order condition is:

$$
\frac{\partial f(\bullet)}{\partial M_{i}}+\frac{\partial f(\bullet)}{\partial M_{g}} \frac{\partial M_{g}}{\partial M_{i}}=W^{D}+\gamma N S_{d}+\gamma N\left(1-S_{d}\right) A_{d}
$$

Or, equivalently:

$$
\frac{\partial f(\bullet)}{\partial M_{i}}=\gamma+W^{D}+\gamma N S_{d}+\gamma N\left(1-S_{d}\right) A_{d}
$$

In this case, $M_{i}^{*}$ is inversely related to $\gamma, W^{D}, N$, and $S_{d}$, as in case I, but also to the altruism parameter $A_{d}$. In the special case of a single donor, $S_{d}=1$, the last term in (5) drops out, and this case is identical to case II, the fully altruistic donor. For $S_{d}<1$ in this case, $M_{i}^{*}$ exceeds the optimal value, but is less than its value in case I, where the donor places zero valuation on the success of projects it does not fund.

To this point, $M_{g}$ has been defined as a pure public good-nonexcludable and fully nonrival. This assumption best fits the case of government administrators (e.g. in the Finance or Planning Ministries) whose decisions equally affect all projects. However, decisions of some administrators will affect only projects in a particular sector (such as health, agriculture, or energy). Other decisions may affect only a single project. We therefore consider variations on the model in which $M_{g}$ is a public good with (at least 
partial) rivalry or "congestion externalities, " and the total external costs to other projects of hiring $M_{i}$ no longer increase proportionately with the total number of projects.

Sector-specific externalities imply that $\gamma>0$ for all projects in the same sector as project $i$, and $\gamma=0$ for projects in all other sectors. One could analyze this case by revising the value function (2.1) to include sector-specific $\gamma_{\mathrm{s}}$, project totals and shares. As a simpler alternative to proliferating terms in this way, equation (2.1) could be applied separately to each sector, redefining $M, M_{g}, N$, and $S_{d}$ in terms of the number of (for example) health sector administrators and projects. More generally, $\gamma$ could vary across projects even within sectors, in which case it can simply be added up over projects funded by donor $d$ and over projects funded by other donors. Suppose there are $j$ projects funded by donor $d$ other than project $i$, and $k$ projects operated by all other donors in the sector. Then, the first-order condition of (5) becomes:

$$
\frac{\partial f(\bullet)}{\partial M_{i}}=\gamma_{i}+W^{D}+\sum_{j \neq i} \gamma_{j}^{d}+A_{d} \sum_{k} \gamma_{k}^{-d}=\gamma_{i}+W^{D}+N_{d} \overline{\gamma_{j}}+A_{d} N_{-d} \overline{\gamma_{k}}
$$

where $\bar{\gamma}_{j}$ denotes the mean value of the marginal product of $M_{g}$ on the $N_{d}$ projects funded by $d$ other than $i$, and $\gamma_{k}$ denotes the mean value of the marginal product of $M_{g}$ on the $N_{-d}$ projects funded by other donors. Equivalently, (5.1) can be written as:

$$
\frac{\partial f(\bullet)}{\partial M_{i}}=\gamma_{i}+W^{D}+\overline{\gamma_{j}} N S_{d}+\overline{\gamma_{k}} N\left(1-S_{d}\right) A_{d}
$$

As before, $M_{i}^{*}$ varies with $W^{D}, N, S_{d}$, and $A_{d}$, but now with $\bar{\gamma}_{j}$ and $\overline{\gamma_{k}}$ instead of $\gamma$.

There are multiple ways to think of the polar case of full rivalry in $M_{g}$. As one example, the external cost to other projects, $\gamma$ associated with a unit increase in $M_{i}$ (and decrease in $M_{g}$ ) could be borne entirely by a single project, if the administrator leaving government devoted all of his or her time to that project. This case is an extreme form of

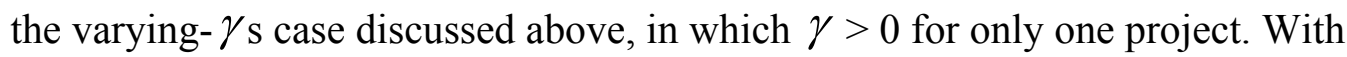
uncertainty, this cost would be incurred by each of the other $N$ projects with probability $\frac{1}{N}$, and the probability the unlucky project belongs to donor $d$ is $S_{d}$. Alternatively, each administrator could expend $\frac{1}{N}$ of his or her time on each of the $N$ projects. In this case, the marginal product of $M_{g}{ }_{i}^{N} \frac{\gamma}{N}$ and donor $d$ maximizes:

$$
\operatorname{Max}_{M_{i}} \quad V_{i}^{d}=f\left(M_{i}, \frac{M_{g}\left(M_{i}\right)}{N}\right)-W^{D} M_{i}-\frac{\gamma}{N} M_{i} N S_{d}-\frac{\gamma}{N} M_{i}\left(1-S_{d}\right) A_{d}
$$


From the necessary first-order condition, we obtain:

$$
\frac{\partial f(\bullet)}{\partial M_{i}}=\frac{\gamma}{N}+W^{D}+\gamma S_{d}+\gamma\left(1-S_{d}\right) A_{d}
$$

The number of projects other than $i, N$, is now inversely related to the marginal product of $M_{i}$, and therefore positively to $M_{i}^{*}$. The external cost imposed on other projects no longer increases with $N$ when each administrator hired away from the government to manage donor projects devotes $\frac{1}{N}$ of his or her time to decisions affecting, individually, each of the $N$ projects, or acts as the counterpart for only one project. The cost incurred on $d$ 's own project from reducing $M_{g}$ by one unit (in its decision to increase $M_{i}$ by one unit) declines with higher $N$, because the fraction $\frac{1}{N}$ of a bureaucrat's effort that affects project $i$ 's output declines as $N$ increases when $M_{g}$ is rival. $^{9}$

For intermediate cases between the polar extremes of fully rival and fully nonrival $M_{g}$, the effects of $N$ on $M_{i}^{*}$ are ambiguous. Specifically, less than full congestion of $M_{g}$ implies that the externality $\gamma$ is divided among the $N$ other projects by some number $n<N$, where $n$ is a positive and monotonic function of $N$, for example $\sqrt{N}$. Then the first-order condition for choosing $M_{i}$ is:

$$
\frac{\partial f(\bullet)}{\partial M_{i}}=\frac{\gamma}{\sqrt{N}}+W^{D}+\gamma S_{d} \frac{\sqrt{N}}{N}+\gamma\left(1-S_{d}\right) A_{d} \frac{\sqrt{N}}{N}=\frac{\gamma}{\sqrt{N}}+W^{D}+\frac{\gamma S_{d}}{\sqrt{N}}+\frac{\gamma\left(1-S_{d}\right) A_{d}}{\sqrt{N}}
$$

The derivative of 6.2 with respect to $\sqrt{N}$ is :

$$
\frac{\gamma}{N}+\gamma S_{d}+\gamma\left(1-S_{d}\right) A_{d}
$$

Therefore, the marginal product of $M_{i}$ increases, and $M_{i}^{*}$ decreases, with $\sqrt{N}$ (and hence with $N)$, if $\frac{1}{N}>S_{d}+\left(1-S_{d}\right) A_{d}$. This condition will hold for any realistic values of $N, S_{d}$ and $A_{d}$.

Another difference in the case of rival as opposed to nonrival public good input $M_{g}$ is that the marginal product of $M_{i}$ at $M_{i}^{*}$ is lower in every case $\left(0<A_{d}<1, A_{d}=0\right.$, and $A_{d}=1$ ), because costs external to other projects are no longer multiplied by $\mathrm{N}$.

\footnotetext{
${ }^{9}$ This case essentially represents the implication of Olson's (1965) model that collective action problems worsen when "group size" is larger. Olson's logic applied only to rival public goods (Hardin 1982).
} 
Therefore, $M_{i}^{*}$ (and the socially efficient level of $M_{i}$ ) are higher: bureaucratic quality will be lower, but so will be the socially efficient level of bureaucratic quality.

Other simplifying assumptions could be relaxed. One could allow $W^{D}$ to vary with the distribution of aid shares, with smaller donors taking the lead in bidding up the wages of top civil servants. Or, the productivity of managers could be allowed to vary continuously. In this case, donors would always hire the best managers. In contrast, when high-quality managers are homogeneous, supply responses might tend to equalize the quality of donor-employed and government-employed managers in the very long run.

\section{Measurement}

Predictions from the model imply that bureaucratic quality will erode more in recipients with greater donor fragmentation, i.e. a larger number of donors each with a smaller share of the project market. Bureaucratic quality can be measured by a subjective index available for most countries from the International Country Risk Guide (ICRG), a commercial service providing information on political risks to overseas investors and lenders. $^{10}$

High scores on the ICRG bureaucratic quality variable indicate "autonomy from political pressure," "strength and expertise to govern without drastic changes in policy or interruptions in government services" when governments change, and "established mechanisms for recruiting and training" (PRS Group 1998). Because the ICRG ratings are subjective, and the definition is not very detailed, it is instructive to validate it against a more detailed "Weberian scale" of bureaucratic development from Evans and Rauch (1999). Evans and Rauch surveyed several experts for each of 35 developing countries, inquiring for the period 1970-90 as a whole about various dimensions of bureaucratic structure, including meritocratic recruitment, internal promotion, career stability, and competitiveness of salaries. From the 126 total responses, they constructed country-level averages for each variable. Finally, they construct a "Weberian scale" from 10 items reflecting competitiveness of salaries and attractiveness of public sector careers, relative to the private sector, number of years high officials have been in the civil service, use of civil service exams, etc.

The "Weberian scale" is correlated at .62 with the ICRG bureaucratic quality index, averaged over all years through 1990 for which all data are available (see Figure

\footnotetext{
${ }^{10}$ See www.prsgroup.com for more information. Among the various governance indicators used in the literature (see Kaufmann et al. 2003; Knack 2003),the ICRG data are unique in covering the majority of nations over a relatively long period of time. The ICRG data have been published since 1982 . The bureaucratic quality rating was provided on a 0-6 scale through 1998, and on a 0-4 scale thereafter. In the analysis below, ratings from 1999 onward are multiplied by 1.5 to make them comparable with the 1982 97 ratings.
} 
Figure 1

\section{Weberian scale \& ICRG, 1982-90}

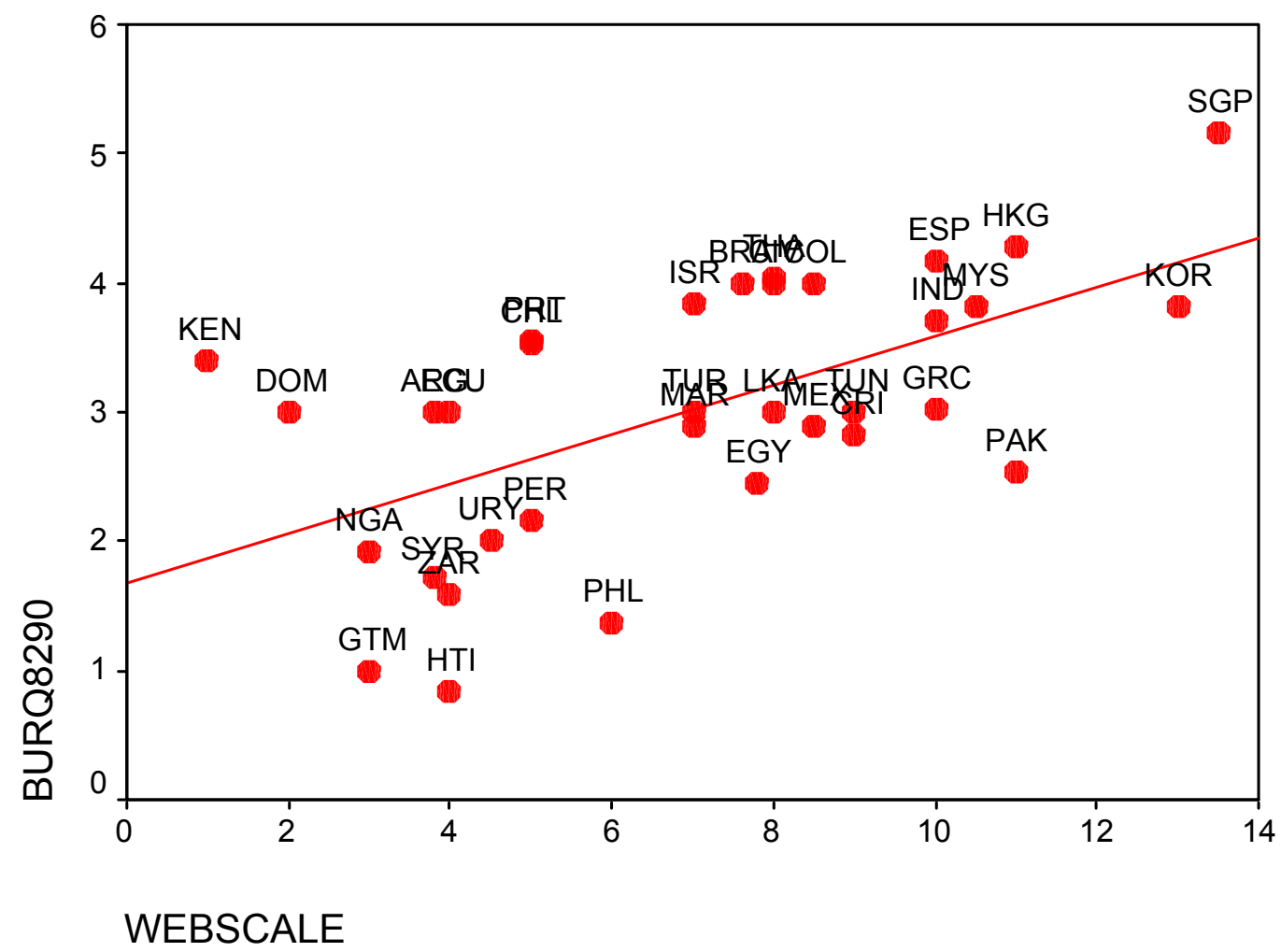

1). This relationship remains strongly significant when we control for per capita income, which in contrast to the Weberian scale is not a significant predictor of the ICRG measure when they are both included in a regression. ${ }^{11}$

Donor fragmentation is calculated as: $1-\sum \mathrm{S}_{\mathrm{d}}{ }^{2}$, or one minus the sum over all donors of their squared aid shares. This measure is computed using two alternative data sources. The official OECD-DAC (Development Assistance Committee) data base of "Geographic Distribution of Financial Flows to Aid Recipients" provides a breakdown of annual disbursements by various bilateral and multilateral donor agencies, treating the various UN agencies as distinct. From these data, an index of donor fragmentation can be calculated for each recipient for each year. The index is then averaged over the relevant period for each recipient. To construct the index, a Herfindahl index of donor concentration is first calculated, by summing the squared shares of aid over all donor

${ }^{11}$ We use the Evans-Rauch Weberian index only to validate the ICRG variable, because it is available for far fewer countries and with no time series variation. 
agencies. ${ }^{12}$ The Herfindahl index, which ranges from 0 to 1 , is then subtracted from 1 , and multiplied by 100, to form a fragmentation index, with high values indicating greater fragmentation. The formula yields higher values as the number of donors increases, and/or as their aid shares become more equal, i.e. where there is no dominant donor. Values among major aid recipients, averaged over 1982-2000, range from 28.4 for Gabon to 91.6 for Tanzania.

Year-by-year changes in this fragmentation index, averaged over all countries, show an upward trend from 1975 onward. This increase largely reflects an increase in the number of DAC donors. For example, the European Bank for Reconstruction and Development (EBRD) was founded in 1991 to aid the transition economies in Eastern Europe and former Soviet Union. Over time, some aid recipients, such as Greece and Portugal, became donors. The increasing trend in fragmentation, however, likely overstates any worsening of donor coordination. Increases in budget support and in the prevalence of sectorwide approaches in some recipients represents a countervailing trend over the last decade or so.

In addition to the DAC disbursements data, the Development Gateway's AiDA (Accessible Information on Development Activities) data base is used to construct an alternative fragmentation index. This source contains records provided by the DAC and other sources on hundreds of thousands of investment projects and other activities financed by various donor agencies. A count of projects sponsored by each donor can be made. From these counts, a fragmentation index is computed from donors' shares of projects. Fragmentation indexes were computed two different ways, first treating each funding nation (e.g. the USA) or multilateral institution as a single donor, and second, treating agencies or departments as separate donors (for example, USAID and USDA). The mean for the first index is (by construction) somewhat higher, but the two indexes are correlated at .92, and results differ very little when one is chosen instead of the other. Results reported in the tables below use the first index. For this project-based fragmentation index for the post-1982 period, values range from 15.9 for Suriname to 90.5 for Senegal.

Project counts and aid volumes provide somewhat different pictures of donor fragmentation. The two indexes are correlated at only .45. Indexes based on the number of projects may reflect actual problems associated with lack of donor coordination better than fragmentation indexes based on aid volumes, for which budget support provided by many donors could produce a high value. A disadvantage of the project data, however, is

${ }^{12}$ O'Connell and Saludo (2001) compute Herfindahl indexes of donor concentration for aid recipients in Africa in the 1990s using the DAC data. 
that unlike the aid volume data, one cannot generate annual fragmentation values, because about 60 percent of the activities included in AiDA lack project start and end dates. Indexes computed for any given subperiod require dropping all projects without start dates. Particularly for years before $1987^{13}$, such indexes will therefore be based on very incomplete project data. However, it is likely that fragmentation is fairly stable across countries over time; e.g. the fragmentation indexes for 1982 and 1997 based on aid volumes are correlated at .87. An index based on all AiDA records (some dating to the late 1940s) turns out to be correlated with one based on activities with start dates of 1990 or later at .81, so these problems with the data may not matter much in practice.

Both fragmentation measures are equally subject to some criticisms. Most notably, neither donor expenditure shares nor project count shares necessarily accurately reflect the level of involvement and influence in a recipient's development program. Neither measure distinguishes other characteristics of donors, only their "market shares." One donor may undertake its activities in ways that are less intrusive and less institutionally corrosive than another donor with a similar share of aid.

Fragmentation can be computed for different aid sectors, such as education, health, and water, because projects (in AiDA) and aid commitments (but not disbursements, in the DAC data) are coded by sector. A high level of fragmentation overall is in principal consistent with donor specialization and hence low fragmentation in individual sectors. Mean levels of fragmentation in fact are somewhat - but not dramatically-lower within individual sectors. However, in countries where fragmentation overall is high, fragmentation within sectors also tends to be high.

The AiDA data base can also be used to construct a project proliferation measure from the total count of projects recorded in a period (with or without adjusting for size of the recipient country), subject to the limitations noted above. The number of projects with start dates of 1982 and later are highest for India, with 3,800, and Tanzania, with 2,758. Correlations of project counts with donor fragmentation are positive and significant but modest in strength, whether fragmentation is computed from disbursement shares (.39) or project count shares $(.36)$.

Predictions of the model regarding the impact of project counts are ambiguous. In the fully nonrival case, the number of managers hired by donor $\mathrm{d}$ for project $\mathrm{i}, \mathrm{M}_{\mathrm{i}}$, declines with $\mathrm{N}$, the number of projects. However, if it declines less than proportionately with increases in $\mathrm{N}, \mathrm{N}^{*} \mathrm{M}_{\mathrm{i}}$ (the total number of managers hired to work on donor-funded projects) would increase with $\mathrm{N}$. This is consistent with a common view within the aid

${ }^{13}$ The number of projects with start dates for 1987 is five times the number for 1986, and the number doubled from 1994 to 1995, suggesting that some donors failed to report start dates until recently. 
industry that project proliferation tends to undermine country ownership and bureaucratic quality.

Deteriorating bureaucratic quality is predicted to be less severe in recipients where donors are more altruistic, in the sense that they value success of other donors' projects as much (or nearly as much) as their own. Multilateral donors are likely to be more altruistic in this sense than bilaterals for several reasons. Donor nations set up multilateral agencies in part to make them less sensitive to the political pressures that often lead bilaterals to pursue objectives not fully consistent with those of recipient or other donor nations (Martens et al. 2002: 37, 47, 188-89; Degnbol-Martinussen and Engberg-Perdersen 1999: 120, 128). Also, some multilaterals include recipient nations in their decision making. The activities of the UN's development agencies are less influenced by the specific national security and commercial interests of the bilateral donors, and recipient nations can exercise influence as members of these organizations (Degnbol-Martinussen and Engberg-Perdersen 1999: 22; Martens et al. 2002: 192). The share of aid from UN agencies, and from the international financial institutions (or IFIs, including the World Bank, IMF, and regional development banks) are therefore used as proxies for the degree of altruism among donors operating in the recipient country. ${ }^{14}$

Aid policy in a group of small "like-minded donors"-Canada, Denmark, the Netherlands, Norway, and Sweden — has differed from other bilateral donors in important ways. National defense, security and business motives are given less emphasis, in favor of humanitarian concerns and preferences for international cooperation (e.g., DegnbolMartinussen and Engberg-Perdersen 1999: 89). ${ }^{15}$ The share of aid from these five countries is therefore used as an additional proxy for donor altruism.

\section{Empirical Tests}

If donor fragmentation erodes bureaucratic quality, then countries with higher fragmentation should exhibit declining scores on the ICRG bureaucratic quality variable over time, relative to other countries. Accordingly, the dependent variable analyzed is the

\footnotetext{
${ }^{14}$ These arguments do not apply to EU aid, as decisions are made by serving politicians from member states, instead of by executive boards with genuinely devolved control. Unanimity in the EC Council and strong competition among EU member countries over contracts also differentiate the EU from other multilaterals (Martens et al. 2002: 37, 47, 192-93; also see Degnbol-Martinussen and Engberg-Perdersen 1999: ch. 7).

${ }^{15}$ Despite having "the most altruistic and progressive aid programs," these donors tend to "proliferate" their aid (scattering it across many recipients and thereby contributing to higher fragmentation) more than do other bilateral donors with a focus on former colonies or geo-strategic interests in a particular region (Acharya et al. 2003). The fragmentation index should capture any negative impacts from this practice at the country level, however. Controlling for fragmentation, therefore, the share of aid from the like-minded donors is hypothesized to have positive effects.
} 
end of period (2001) value minus the initial (1982 for most countries, and 1984 for most others) value. ${ }^{16}$ Control variables include aid levels, the initial level of bureaucratic quality, the length of the interval over which ICRG data are available for each country, population growth, and per capita income growth. ${ }^{17}$

Aid intensity - measured by official development assistance (ODA) as a percentage of GNI, averaged over 1982-2000 - may affect bureaucratic quality independently of the fragmentation of aid among donors. ${ }^{18}$ Aid could be a source of revenue used to increase public sector salaries, attracting and retaining more talented and experienced civil servants. It could also be delivered in the form of technical assistance designed to increase administrative capacity. High aid levels can undermine public sector institutions, however (e.g., Brautigam 2000). Leaders with short time horizons will face little incentive to use aid to build a capable bureaucracy (Clague et al. 1996), but instead may use aid for patronage purposes - for example by subsidizing employment in the public sector and in state-operated enterprises - to tighten their grip on power. As rents available to those controlling the government increase when aid levels are higher, resources devoted to obtaining political influence increase. ${ }^{19}$ Workers face incentives to reallocate time away from acquiring productive knowledge and skills, toward gaining the knowledge and skills useful for obtaining a share of aid revenues. Talent is reallocated from productive to redistributive activities. By making control of the government a more valuable prize, aid can even increase political instability (Grossman 1992). Maren (1997) blames Somalia's civil wars on competition for control of large-scale food aid. The net effect of aid on bureaucratic quality is therefore ambiguous.

Inclusion of the initial level of bureaucratic quality captures regression-to-themean effects, and controls for the limited opportunity of highly rated countries to increase their scores (the ICRG measure of bureaucratic quality has an upper bound of 6). If there are economies or diseconomies of scale in establishing effective institutions, population increases could improve or worsen bureaucratic quality. ${ }^{20}$ The length of the period

\footnotetext{
${ }^{16}$ Annual variation in the data is not used because effects on bureaucratic quality may show up only with substantial lags.

${ }^{17}$ The approach here is analogous to the case of growth regressions (and controlling for initial income), in contrast to income levels accounting. Aid/GNI, population and income data are taken from the World Development Indicators.

${ }^{18}$ Correlations between donor fragmentation and aid intensity over 1982-2000 are below .10. Note that fragmentation does not necessarily rise with aid levels: doubling all donors' aid while keeping the number of donors unchanged leaves fragmentation values unchanged.

${ }^{19}$ Corruption and aid can be mutually reinforcing, as elites "whose livelihoods depend mostly on aid...become an interest group that will fight for continued aid...to ensure themselves continued privileges and income" (Degnbol-Martinussen and Engberg-Pedersen 1999: 273).

${ }^{20}$ Knack and Azfar (2003) critically review the various arguments for economies and diseconomies of scale in governance, and show that cross-sectional evidence indicating larger countries are more corrupt is
} 
covered by ICRG data is also controlled for, because countries have more opportunity to improve (or worsen) the quality of their bureaucracies over a longer time. ${ }^{21}$ Increases in per capita income could improve bureaucratic quality by increasing tax revenues if government funds are a binding constraint. If bureaucratic quality is inferred by ICRG in part from observations of economic performance, controlling for changes in per capita income may have the effect of removing spurious changes in scores.

Bureaucratic quality of governance may be influenced by numerous other factors, such as religious or legal traditions, or colonial heritage (see Swamy et al. 2001; Treisman 2000; La Porta et al. 1999). A convenient implication of using the change in bureaucratic quality as the dependent variable is that factors such as these, which are invariant over very long periods of time, are unlikely to matter much. In contrast, it is unlikely that the quality of the bureaucracy would have fully adjusted to aid intensity and fragmentation already by the beginning of the sample period considered here, as donor proliferation began in earnest only in the 1970s and continued building up into the 1980s (Morss 1984: 465). ${ }^{22}$

Results are shown in Table 1. Equation 1 includes all aid recipients with initial per capita incomes (measured at purchasing power parity) below $\$ 7,000$, and with aid/GNI averaging more than .03 percent. Improvement in bureaucratic quality is associated with lower initial levels of bureaucratic quality, as expected, and with a longer time spell over which data on bureaucratic quality are available. Improvement is greater where GDP growth is higher, although the significance of this relationship is marginal and causality likely goes in both directions (Chong and Calderon 2000). Both aid variables are significant: higher levels of aid, and greater fragmentation of aid (computed from project counts) are associated with larger declines in bureaucratic quality. A 12 percentage point increase in aid/GNI is associated with a half-point drop in quality of the bureaucracy. ${ }^{23}$ A similar-sized decrease in bureaucratic quality is associated with an increase of 30 in the 0-100 donor fragmentation index.

an artifact of sample selection bias.

${ }^{21}$ Countries are included in the sample only if there are at least three years of ICRG data on bureaucratic quality available. The average in our main high-aid sample is 16.4 years, out of a maximum of 19.

${ }^{22}$ For all developing countries, aid/GNP averaged about 2 percent, 3 percent, 5 percent and 6 percent, respectively, in the 1960s, 1970s, 1980s, and 1990s. For Sub-Saharan Africa, the figures are 3 percent, 7.5 percent, 11.2 percent and 15.3 percent. For all developing countries, donor fragmentation averaged .56 in 1975 and .69 in 2000. For Africa, the figures are .69 and .83 .

${ }^{23}$ Using similar methodology and data, Knack (2001) finds that higher aid levels were associated with declines in the quality of governance, as measured by an index of corruption, rule of law, and bureaucratic quality variables from the ICRG. Knack (forthcoming) finds no evidence that higher aid levels promoted democratization, based on the Freedom House measures of political freedoms and civil liberties over the 1975-2000 and 1990-2000 periods. Neither study addresses donor fragmentation (or altruism) issues. 
Table 1. Donor Fragmentation and Bureaucratic Quality

\begin{tabular}{|c|c|c|c|c|c|c|}
\hline \multirow{2}{*}{$\begin{array}{l}\text { Equation } \\
\text { Period }\end{array}$} & 1 & 2 & 3 & 4 & 5 & 6 \\
\hline & \multicolumn{4}{|c|}{$1982-2001$} & \multicolumn{2}{|c|}{$1990-2001$} \\
\hline Sample & $\begin{array}{c}\mathrm{Aid} / \mathrm{GNI} \\
>.03 \%\end{array}$ & $\begin{array}{c}\mathrm{Aid} / \mathrm{GNI} \\
>7 \%\end{array}$ & $\begin{array}{c}\mathrm{Aid} / \mathrm{GNI} \\
>7 \%\end{array}$ & $\begin{array}{c}\text { Sub- } \\
\text { Saharan } \\
\text { Africa }\end{array}$ & $\begin{array}{c}\mathrm{Aid} / \mathrm{GNI} \\
>7 \%\end{array}$ & $\begin{array}{c}\text { Sub- } \\
\text { Saharan } \\
\text { Africa }\end{array}$ \\
\hline Constant & $\begin{array}{l}2.757 \\
(0.647)\end{array}$ & $\begin{array}{c}3.834 \\
(1.757)\end{array}$ & $\begin{array}{c}2.229 \\
(1.517)\end{array}$ & $\begin{array}{c}6.053 \\
(1.843)\end{array}$ & $\begin{array}{c}4.150 \\
(1.522)\end{array}$ & $\begin{array}{c}6.471 \\
(1.637)\end{array}$ \\
\hline $\begin{array}{l}\text { Initial bureaucratic } \\
\text { quality }\end{array}$ & $\begin{array}{c}-0.851^{* *} \\
(0.085)\end{array}$ & $\begin{array}{c}-1.123 * * \\
(0.171)\end{array}$ & $\begin{array}{c}-1.100 * * \\
(0.188)\end{array}$ & $\begin{array}{c}-1.056^{* *} \\
(0.130)\end{array}$ & $\begin{array}{c}-1.179 * * \\
(0.162)\end{array}$ & $\begin{array}{c}-1.059 * * \\
(0.134)\end{array}$ \\
\hline No. of years covered & $\begin{array}{l}0.067^{*} \\
(0.027)\end{array}$ & $\begin{array}{c}0.013 \\
(0.094)\end{array}$ & $\begin{array}{c}0.070 \\
(0.085)\end{array}$ & $\begin{array}{l}-0.104^{\#} \\
(0.057)\end{array}$ & $\begin{array}{l}-0.018 \\
(0.080)\end{array}$ & $\begin{array}{l}-0.085 \\
(0.054)\end{array}$ \\
\hline $\begin{array}{l}\text { Population change/ } \\
\text { initial population }\end{array}$ & $\begin{array}{l}-0.176 \\
(0.155)\end{array}$ & $\begin{array}{r}0.150 \\
(0.400)\end{array}$ & $\begin{array}{r}0.029 \\
(0.320)\end{array}$ & $\begin{array}{l}0.898^{*} \\
(0.319)\end{array}$ & $\begin{array}{c}0.264 \\
(0.285)\end{array}$ & $\begin{array}{c}0.303 \\
(0.528)\end{array}$ \\
\hline GDP p.c. change/ & $0.090^{\#}$ & 0.156 & 0.159 & $0.188^{*}$ & $0.173^{\#}$ & 0.094 \\
\hline Initial GDP p.c. & $(0.052)$ & $(0.128)$ & $(0.139)$ & $(0.071)$ & $(0.103)$ & $(0.080)$ \\
\hline $\mathrm{Aid} / \mathrm{GNI}$ & $\begin{array}{r}-0.042 * * \\
(0.015)\end{array}$ & $\begin{array}{l}-0.027 \\
(0.019)\end{array}$ & $\begin{array}{l}-0.005 \\
(0.020)\end{array}$ & $\begin{array}{c}-0.046^{* *} \\
(0.012)\end{array}$ & $\begin{array}{l}-0.022 \\
(0.015)\end{array}$ & $\begin{array}{r}-0.042 * * \\
(0.012)\end{array}$ \\
\hline $\begin{array}{l}\text { Fragmentation (AiDA } \\
\text { activities counts) }\end{array}$ & $\begin{array}{l}-0.017 * \\
(0.007)\end{array}$ & $\begin{array}{l}-0.026^{\#} \\
(0.013)\end{array}$ & & $\begin{array}{c}-0.056 * * \\
(0.015)\end{array}$ & $\begin{array}{c}-0.028 * * \\
(0.010)\end{array}$ & $\begin{array}{c}-0.044 * \\
(0.019)\end{array}$ \\
\hline $\begin{array}{l}\text { Fragmentation (DAC } \\
\text { (disbursements) }\end{array}$ & & & $\begin{array}{l}-0.019 * \\
(0.009)\end{array}$ & & & \\
\hline $\mathrm{N}$ & 96 & 30 & 30 & 30 & 32 & 30 \\
\hline $\mathrm{R}^{2}$ & .58 & .67 & .64 & .82 & .73 & .84 \\
\hline Std. error of est. & 0.92 & 1.02 & 1.07 & 0.72 & 0.96 & 0.72 \\
\hline Mean, dep. var. & 0.05 & -0.17 & -0.17 & -0.73 & -0.33 & -0.75 \\
\hline
\end{tabular}

Robust standard errors are in parentheses. ${ }^{*}, *$, and ${ }^{* *}$, respectively, indicate significance at the $.10, .05$ and .01 level for two-tailed tests.

For many aid recipients in this 96-country sample, foreign assistance is sufficiently modest that there is little reason to expect the fragmentation of aid to matter much. For samples consisting of high-aid countries, fragmentation should matter more. This result is confirmed in several tests (not reported in the table) that progressively eliminate countries with increasing thresholds of aid/GNI, which show coefficients for fragmentation progressively increasing (in absolute value). ${ }^{24}$ Equation 2 includes only 30 high-aid countries with aid/GNI exceeding 7 percent. Some control variables significant in the larger sample are not in this smaller sample. Aid level, in particular, is less likely to be significant because its variation is reduced by the way the sample is constructed.

Fragmentation remains marginally significant, with a coefficient half again as large as in equation 1 .

\footnotetext{
${ }^{24}$ An alternative approach is to test in the full sample an interaction between aid/GNI and fragmentation. The coefficient for this interaction has the anticipated (negative) sign but is not significant.
} 
Equation 3 retains this high-aid sample, but substitutes the DAC-based fragmentation index for the AiDA-based index. This index also has a negative coefficient, significant at the .05 level. $^{25}$

Causality is potentially an issue when examining the relationship between aid decisions and aspects of the quality of governance. Conceivably, donors may respond to deteriorating administrative capacity by increasing technical assistance and other forms of aid. If so, negative coefficients on aid variables in Table 1 could reflect the impact of bureaucratic quality on aid rather than the other way around. In general, however, donor policies at least nominally reward well-governed recipients with higher aid, not lower aid. ${ }^{26}$ Consistent with these stated policies, tests correcting for potential endogeneity of aid produce higher (in absolute value) coefficients on aid/GNI, and indicate that causality runs from aid to the quality of governance (Knack 2001).

In contrast to the case for aid/GNI, good exogenous instruments for donor fragmentation are not available. However, there is intuitively even less reason to expect that the number of donors would increase in response to an observed deterioration in bureaucratic quality, than that aid levels would increase. Nevertheless, we conducted an informal causality test, taking advantage of our ability to construct DAC-based fragmentation indexes for particular sub-periods. If fragmentation is a response to administrative decline, fragmentation measured toward the end of the period should "predict" changes in bureaucratic quality better than fragmentation measured earlier in the period. Accordingly, we constructed fragmentation values for 1982-90 and 19912000. When both are included in a regression otherwise identical to that in equation 3 of Table 1, the coefficient for the 1982-90 variable is -.026, significant at .11, and the coefficient for the 1991-2000 variable is +.017 and does not approach significance. When they are included one at a time, the former is significant (at the .05 level) with a coefficient of -.016, and the latter is not significant (even at the .20 level), with a coefficient of -.012. These results are consistent with the hypothesis that donor fragmentation contributes to bureaucratic decline, and inconsistent with the hypothesis that bureaucratic decline produces fragmentation.

\footnotetext{
${ }^{25}$ Unlike the AiDA-based index, the DAC-based index is not significant for larger samples that include low-aid countries.

${ }^{26}$ Examples include the World Bank's concessional aid to poorer aid recipients, USAID, and the soon-to-be-implemented U.S. Millennium Challenge Account. Aid allocation policies of UN and many other donor agencies do not intentionally penalize or reward recipients based on factors such as corruption levels and bureaucratic quality. These agencies sometimes may increase aid to countries with deteriorating economic conditions, which may in turn adversely affect bureaucratic quality, but inclusion of income per capita change as a regressor should capture this effect.
} 
Equation 4 differs from equation 2 only in substituting Sub-Saharan African countries for the high-aid sample. Most African aid recipients are particularly vulnerable to institutional destruction from "poaching" and by-passing government, due to a short history of self-government, limited supplies of skilled labor, low incomes and public sector salaries, low foreign investment and high aid levels (Morss 1984; Berg 1997; Klitgaard 1997; O'Connell and Soludo 2001; Brautigam and Knack forthcoming). ${ }^{27}$

Fragmentation is highly significant in this sample of Sub-Saharan African countries, with a coefficient in equation 4 more than double that from the high-aid sample in equation 2. (Figure 2 shows this partial relationship between fragmentation and change in bureaucratic quality, controlling for the effects of other variables.) Moreover, the explanatory power of the model overall is higher, and every regressor is statistically significant. On average, bureaucratic quality ratings declined in this African sample, by nearly three-quarters of a point on the 0-6 scale (several times higher than the average decline for the high-aid sample in equations 1-3). Declines are significantly greater where the data cover a longer period of time. Population and income growth are associated with more favorable trends in bureaucratic quality.

Equations 5 and 6 analyze the change in bureaucratic quality over the post-Cold War period, 1990-2001. Independent variables are modified accordingly; for example, initial bureaucratic quality is measured for 1990, aid intensity and fragmentation cover only the period 1990-2000, etc. There are two major reasons to hypothesize that the negative impact of aid on the quality of governance might have weakened after 1990. First, starting at about that time donors began to emphasize the crucial importance of the quality of governance for development. Bilateral donors and international financial institutions are now heavily engaged in programs to reduce corruption, improve public expenditure management and tax administration systems, and support democratization in recipient countries. Second, the end of the Cold War allowed the U.S. and other donors to more selectively target aid, rather than using aid to strengthen corrupt but strategically important autocracies.

\footnotetext{
${ }^{27}$ In the 30 African countries in the equation 4 sample, aid/GNI averages 12.8 percent. Nineteen of them are in the high-aid sample of countries exceeding 7 percent; of these, 16 exceed 10 percent, 10 exceed 15 percent, and 5 exceed 20 percent. South Africa and resource-dependent Nigeria are the only countries below 2 percent.
} 
Figure 2

\section{Donor fragmentation \& bureaucratic quality}

\section{(partial plot, Sub-Saharan Africa)}

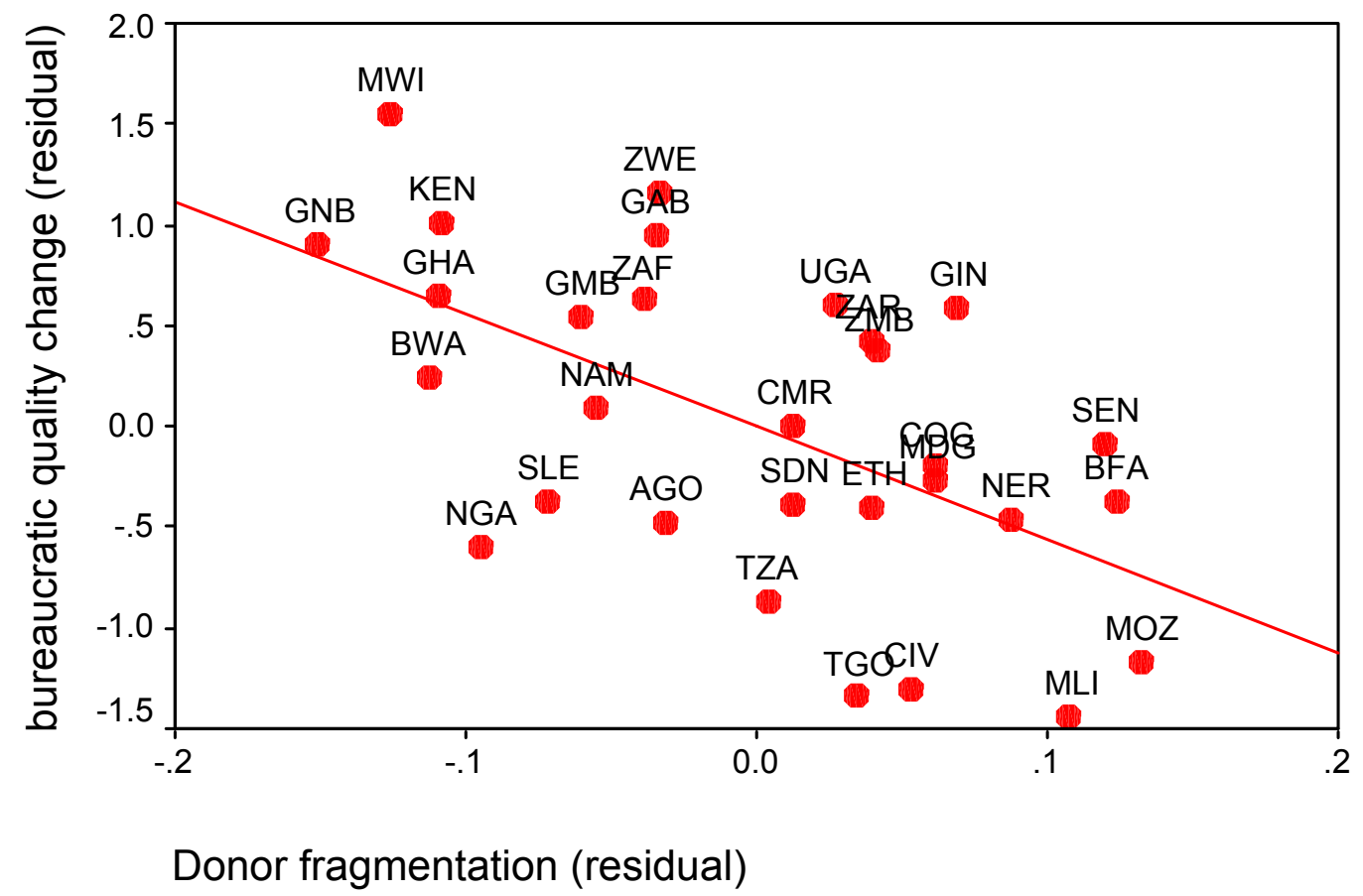

Equation 5 analyzes a high-aid sample of 32 recipients with aid/GNI exceeding 7 percent in the 1990-2000 period. Donor fragmentation is highly significant. Equation 6 analyzes 30 Sub-Saharan African aid recipients for the same period. Aid intensity and donor fragmentation are both highly significant. For both samples of countries, aid coefficients are similar in equations 5 and 6 to those in the corresponding equations (2 and 4) for the longer 1982-2001 period. Hence, there is no evidence that the end of the Cold War or donors' increased emphasis on the quality of governance has altered the relationship between aid practices and bureaucratic quality.

Table 2 builds on equations 2 and 3 (for the high-aid sample, 1982-2001) of Table 1 , by adding our crude proxies for donor altruism. Coefficients for UN aid share and IFI aid share are positive in equation 1, as hypothesized, but insignificant. The coefficient for like-minded donors' aid share is negative and insignificant. The UN and IFI coefficients are not significantly different from each other, so they are added together as "multilateral aid" in equation 2. This variable approaches but does not quite attain significance at conventional levels. The addition of these altruism proxies increases the magnitude and significance of the fragmentation coefficient, relative to equation 2 of Table 1. 
Table 2. Donor Altruism and Bureaucratic Quality: High-Aid Sample, 1982-2001

\begin{tabular}{|c|c|c|c|c|}
\hline \multirow{2}{*}{$\begin{array}{l}\text { Equation } \\
\text { Fragmentation variable }\end{array}$} & \multirow{2}{*}{\multicolumn{2}{|c|}{ AiDA }} & \multirow[t]{2}{*}{3} & \multirow[t]{2}{*}{4} \\
\hline & & & & \\
\hline Constant & $\begin{array}{c}5.051 \\
(1.557)\end{array}$ & $\begin{array}{l}5.125 \\
(1.507)\end{array}$ & $\begin{array}{c}2.780 \\
(1.264)\end{array}$ & $\begin{array}{c}2.730 \\
(1.191)\end{array}$ \\
\hline Initial bureaucratic quality & $\begin{array}{c}-1.120^{* *} \\
(0.206)\end{array}$ & $\begin{array}{c}-1.111^{* *} \\
(0.198)\end{array}$ & $\begin{array}{c}-0.973 * * \\
(0.172)\end{array}$ & $\begin{array}{c}-0.979^{* *} \\
(0.160)\end{array}$ \\
\hline No. of years covered & $\begin{array}{l}-0.022 \\
(0.077)\end{array}$ & $\begin{array}{r}-0.032 \\
(0.078)\end{array}$ & $\begin{array}{l}-0.008 \\
(0.069)\end{array}$ & $\begin{array}{l}-0.002 \\
(0.060)\end{array}$ \\
\hline $\begin{array}{l}\text { Population change/ initial } \\
\text { population }\end{array}$ & $\begin{array}{c}0.248 \\
(0.295)\end{array}$ & $\begin{array}{c}0.276 \\
(0.280)\end{array}$ & $\begin{array}{c}0.535 \\
(0.342)\end{array}$ & $\begin{array}{c}0.514 \\
(0.320)\end{array}$ \\
\hline $\begin{array}{l}\text { GDP p.c. change/ } \\
\text { Initial GDP p.c. }\end{array}$ & $\begin{array}{r}0.155 \\
(0.134)\end{array}$ & $\begin{array}{c}0.148 \\
(0.132)\end{array}$ & $\begin{array}{c}0.138 \\
(0.111)\end{array}$ & $\begin{array}{c}0.143 \\
(0.106)\end{array}$ \\
\hline Aid/GNI & $\begin{array}{l}-0.033^{*} \\
(0.014)\end{array}$ & $\begin{array}{l}-0.032^{*} \\
(0.013)\end{array}$ & $\begin{array}{c}0.002 \\
(0.019)\end{array}$ & $\begin{array}{c}0.001 \\
(0.018)\end{array}$ \\
\hline Fragmentation & $\begin{array}{c}-0.045^{* *} \\
(0.012)\end{array}$ & $\begin{array}{c}-0.045^{* *} \\
(0.013)\end{array}$ & $\begin{array}{c}-0.061 * * \\
(0.020)\end{array}$ & $\begin{array}{r}-0.060 * * \\
(0.019)\end{array}$ \\
\hline UN share of aid & $\begin{array}{c}0.042 \\
(0.047)\end{array}$ & & $\begin{array}{l}0.074^{*} \\
(0.031)\end{array}$ & \\
\hline IFI share of aid & $\begin{array}{c}0.029 \\
(0.026)\end{array}$ & & $\begin{array}{l}0.082 * \\
(0.032)\end{array}$ & \\
\hline $\begin{array}{l}\text { "Like-minded donor" share of } \\
\text { aid }\end{array}$ & $\begin{array}{l}-0.020 \\
(0.014)\end{array}$ & $\begin{array}{l}-0.020 \\
(0.014)\end{array}$ & $\begin{array}{c}0.019 \\
(0.012)\end{array}$ & $\begin{array}{c}0.019 \\
(0.011)\end{array}$ \\
\hline Multilateral share of aid & & $\begin{array}{c}0.033 \\
(0.020)\end{array}$ & & $\begin{array}{l}0.079 * * \\
(0.024)\end{array}$ \\
\hline $\mathrm{R}^{2}$ & .74 & .74 & .76 & .76 \\
\hline Std. error of est. & 0.96 & 0.94 & 0.92 & 0.90 \\
\hline Mean, dep. var. & -0.17 & -0.17 & 0.17 & -0.17 \\
\hline
\end{tabular}

Sample includes 30 countries with aid/GNI $>7$ percent. Robust standard errors are in parentheses. $\mathrm{A}^{\#}, *$ and ${ }^{* *}$ respectively indicate significance at $.10, .05$ and .01 level.

Equations 3 and 4 substitute the DAC-based for the AiDA-based fragmentation index. In equation 3 , coefficients are positive for all three altruism variables, and are significant at the .05 level for the UN and IFI shares. As these two coefficients are very similar, they are added together in equation 4 , where the multilateral aid share is significant at the .01 level. The like-minded donor coefficient approaches significance at the .10 level. Again, the addition of these altruism proxies substantially increases the magnitude and significance of the fragmentation coefficient, relative to equation 3 of Table 1.

In other tests not shown in the tables, project proliferation - as measured by project counts from the AiDA database - was not associated with changes in bureaucratic quality. This result holds whether or not one adjusts the project count totals for 
population differences (larger countries tend to have more projects). The lack of any relationship between project proliferation and declining bureaucratic quality is consistent with the ambiguous predictions of the model in section 3 , but is inconsistent with the descriptive literature, which tends to blame equally project proliferation and donor fragmentation for undermining public sector administrative capacity.

\section{Conclusions}

This study provides a formal analysis and empirical evidence suggesting that competitive donor practices, where there are many small donors and no dominant donor, erode administrative capacity in recipient country governments. In their need to show results, donors each act to maximize performance of their own projects, and shirk on provision of the public sector human and organizational infrastructure essential for the country's overall long-term development. ${ }^{28}$ Empirical findings show that bureaucratic quality suffers where aid is fragmented more severely across donors. Informal tests of reverse causality strongly indicate that causation runs from fragmentation to lower quality. Proxies for donor altruism tend to be associated with improving bureaucratic quality, consistent with the model's predictions, although these variables are not always significant.

Even if donor practices contribute to declining bureaucratic quality, this side effect of aid does not necessarily imply that aid overall is counterproductive for development. Donors' use of human resources, however sub-optimal, may sometimes be more efficient than the government's use of them. The implication of this paper is that donor practices produce less damaging side effects when donors have a higher share of the aid "market" in a recipient country or when they are more altruistic (motivated more by development concerns).

This analysis should also not be interpreted as implying that donors should refrain from hiring local staff, or that prevailing salaries for highly qualified civil servants are high enough. The point is rather that donors should not unduly distort the market for skilled labor. The resource injection from high donor-paid salaries potentially has a positive net impact on development, despite the adverse impact on the functioning of government. However, those same benefits could be obtained, without the negative consequences, from using the funds to increase the salaries of underpaid civil servants, or through general budget support. Budget support targeted for increasing salaries of senior and technical staff - particularly where the use of merit systems increases the

\footnotetext{
${ }^{28}$ Bureaucratic quality has been linked to growth in several cross-country studies, including Evans and Rauch (1999) and Keefer and Knack (1997), who measure bureaucratic quality using ICRG data.
} 
presumption that these officials are the ones worth retaining - would weaken incentives faced by qualified staff to defect to aid agencies or other employers.

A range of other reforms could also contribute to the resolution of these problems. Agreements between government and donors are needed on codes governing recruitment, salary and benefit levels, and the use of government officials for part-time consultancy work (Fallon and da Silva 1994: 101). Cohen and Wheeler (1997b: 318) recommend finding ways to tailor training to enhance carefully specified skills directly related to responsibilities within a ministry, without granting academic credentials that facilitate mobility. They also suggest reducing pay disparities by reducing overstaffed lower grades, and using savings to increase upper level salaries. They recognize, however, the potential for political resistance as overstaffing lower grades is a prime source of patronage (Cohen and Wheeler 1997b: 320-21).

The analysis here also underscores the critical importance of organizational capacity building. In particular, multilateral and other agencies under fewer political constraints to demonstrate visible, attributable results should take on increased responsibility for technical assistance in upgrading policymaking, budgeting, and related administrative systems that tend to be victimized by collective action failures among donors. As capacity is improved, the plausibility of any efficiency rationale for project aid (by enabling the tracking of funds) diminishes, and donors may grudgingly accede to growing pressures from the DAC, UN and other international agencies to reduce the emphasis on "their" projects in favor of pooling funds in the form of budget support. Successful implementation of high-level decisions to employ more development-friendly aid modalities will require changing incentives for staff within donor agencies, for example by focusing more on output and country-level indicators, and less on input and project-level indicators. Staff performance appraisals could also take into account written evaluations of job performance from other donor staff, and from government counterparts (Whittington and Calhoun 1988: 307).

Additional reforms could address other aspects of donor coordination problems that detract from the developmental impact of aid. Ongoing efforts by aid agencies to improve donor coordination have focused to date on reducing transactions costs by harmonizing operational policies and procedures, such as standardizing reporting and monitoring systems, ${ }^{29}$ and establishing a Web site to disseminate information on completed and planned country analytic work ${ }^{30}$

\footnotetext{
${ }^{29}$ See "Rome Declaration on Harmonization," February 25, 2003.

${ }^{30}$ See www.countryanalyticwork.net.
} 
The recent trend toward budget support and away from a projects focus by DfiD and a few other donors is often viewed as a means of reducing transactions costs for government officials. However, if budget support is coupled with more complex management requirements and demands by donors for deeper reform and better reporting, transactions costs may change very little, and the main benefits may come in the form of strengthening government systems (OECD 2003: 122). The emergence of more limited pooling schemes like sectorwide programs in Mozambique, Zambia and elsewhere is often viewed as a step toward budget support. However, transactions costs in negotiating and managing these processes have sometimes been enormous (OECD 2003: 116; Riddell 1999: 334).

Other, less conventional solutions require cooperation with and among donors in ways that drastically reduce the diffusion of responsibility. Greater donor accountability for overall results of a country's development program could be enhanced by formally designating a lead donor - whether a multilateral or bilateral agency — which would thereby have an enhanced reputational stake in the country's overall development success. In aid-intensive countries, this scheme would not necessarily reduce the leverage of most recipients over donors, because the market for aid would remain highly contestable: donors wanting to be selected as the lead or dominant (or sole) donor would have to compete, by offering aid on a more favorable basis (such as untying it). ${ }^{31}$ In fact, recipient governments often plead for improved coordination among donors (e.g., see OECD 2003: 121-22). Where such a scheme is resisted by recipient governments, it is more likely to signify principal-agent problems between citizens who are harmed by and government officials who benefit from current donor practices, than to reflect any legitimate fears that smaller, better-coordinated donor groups would impose less development-friendly aid policies.

As an alternative to specializing among countries, donors could specialize by theme or sector, with some specializing in infrastructure, others in social sectors, and others in institutional and capacity building. Multilateral agencies specialize to some degree already, with the regional development banks specializing geographically and the IMF and many UN agencies specializing by theme or sector. Even among the bilaterals, there is some specialization, with Japan tending to focus its aid in East Asia and the Pacific, and on infrastructure and economic sectors, while European donors focus more on Africa, and on social sectors and governance and human rights themes.

\footnotetext{
${ }^{31}$ In economic life generally, contracting with a single supplier does not typically reflect monopoly power by the supplier, but economies of scale and the desire to minimize transactions costs. The situation would be different, of course, were a donor cartel to select lead donors to impose on recipients.
} 
There are strong political forces and other interests working against further increases in specialization, however. Leaving certain problems or countries for other donors to deal with exposes an aid agency to charges by NGOs or the media that it is irresponsibly underfunding critically important development problems. Arcane justifications based on efficiency benefits of donor harmonization and comparative advantage are unlikely to be an effective public relations response. Interagency funding could be a partial solution to this problem. For example, if an aid agency devoted few resources directly to combating infectious disease, but transferred a certain amount of money annually to the WHO or Global Fund to Fight AIDS, Tuberculosis and Malaria for this purpose, it could be inoculated somewhat from accusations of ignoring a major impediment to development. Norway and Sweden both fund education and health sector programs in Ethiopia, but Sweden is arranging to channel its health funding through Norway, while Norway will channel its education funding through Sweden (OECD 2003: 97).

Competition at the global level among aid agencies also tends to inhibit specialization; for example the World Bank attempts to establish intellectual leadership in as many development themes and sectors as possible. Even the five relatively altruistic "like-minded" bilateral donors proliferate aid across many recipients, as a result of "good intentions" according to Acharaya et al. (2003). ${ }^{32}$ Good intentions, however, are a less plausible explanation for this sort of proliferation than the prestige and influence derived from aid agency officials from maintaining a global presence on par with the larger bilateral and multilateral agencies. In recent years, Denmark, the Netherlands, Norway, and Sweden each have decided to focus their aid on fewer than 25 priority countries. An OECD (2001) review of Dutch aid policy lauded this concentration of aid as "a politically difficult and courageous step toward creating the conditions for more efficient development cooperation." However, the share of aid going to the priority countries has not increased markedly if at all in most cases, and aid is still provided to dozens of additional countries. Moreover, there is little or no specialization among the like-minded donors, as the high-priority list for each of them tends to include the same high-aid countries, including Bangladesh, Mozambique, Tanzania, Uganda and Zambia. ${ }^{33}$ Despite the ongoing high-level harmonization initiatives by aid agencies, there remain grounds

${ }^{32}$ In 1999-2001, the Netherlands, Canada, Norway, Sweden and Denmark, respectively, provided aid to $134,130,116,112$ and 87 recipients (Acharya et al. 2003).

${ }^{33}$ By contrast, India is not on the priority list for most of these donors, despite having more poor people (living on under \$1 per day) in 2000 than all of Sub-Saharan Africa and a relatively favorable institutional and policy environment for aid effectiveness. The efforts and impact of small donors are nearly invisible, and their leverage over policy non-existent, in a country as large as India. 
for skepticism that political and bureaucratic exigencies of donors will be trumped by demands for improved aid effectiveness (van de Walle 2001: 233; OECD 2003: 118).

Publicizing various measures of donor performance, by the OECD DAC or by independent organizations such as the Center for Global Development, could marginally improve the incentives faced by aid agencies. Performance measures could include not only the share of aid that is tied, but also measures of how each donor proliferates aid across recipients and sectors (Acharya et al. 2003), the share of aid channeled through multilateral organizations, and the number of missions and reports required relative to aid levels.

\section{References}

Acharya, Arnab, Ana Fuzzo de Lima, and Mick Moore. 2003. “The Proliferators: Transactions Costs and the Value of Aid." Institute of Development Studies.

Arndt, Channing. 2000. “Technical Cooperation.” In F. Tarp, ed., Foreign Aid and Development: Lessons Learnt and Directions for the Future. London: Routledge.

Azam, Jean-Paul, Shantayanan Devarajan, and Stephen A. O’Connell. 2002. “Equilibrium Aid Dependence." Unpublished manuscript, University of Toulouse.

Berg, Elliot. 1997. "Dilemmas in donor aid strategies." In C. Gwin and J. M. Nelson, eds., Perspectives on Aid and Development. Washington, D.C.: Overseas Development Council.

Berg, Elliot. 1993.. Rethinking Technical Cooperation: Reforms for Capacity Building in Africa. New York: UNDP.

Brautigam, Deborah. 2000. Aid dependence and governance. Stockholm: Almqvist \& Wiksell International.

Brautigam, Deborah, and Stephen Knack (forthcoming). "Foreign Aid, Institutions and Governance in Sub-Saharan Africa." Economic Development and Cultural Change.

Chong, Alberto, and Cesar Calderon. 2000. "Causality and Feedback Between Institutional Measures and Economic Growth.” Economics and Politics 12 (1): 69-81.

Clague, Christopher; Philip Keefer, Stephen Knack, and Mancur Olson. 1996. "Property and Contract Rights in Democracies and Dictatorships." Journal of Economic Growth 1: 207-27.

Cohen, John M., and John R. Wheeler. 1997a. "Training and Retention in African Public Sectors: Capacity-Building Lessons from Kenya.” In Merilee S. Grindle, ed., Getting Good Government: Capacity Building in the Public Sectors of Developing Countries. Cambridge, Mass.: Harvard University Press.

Cohen, John M., and John R. Wheeler. 1997b. "Building Sustainable Professional Capacity in African Public Sectors: Retention Constraints in Kenya." Public Administration and Development 17: 307-24. 
Degnbol-Martinussen, John, and Poul Engberg-Pedersen. 2003. Aid: Understanding International Development Cooperation. London: Zed Books.

DeLong, J. Bradford, and Barry Eichengreen. 1993. "The Marshall Plan: History's Most Successful Structural Adjustment Program.” In Rudiger Dornbusch, Wilhelm Nolling, and Richard Layard, eds., Postwar Economic Reconstruction and Lessons for the East Today. Cambridge, MA: MIT Press.

Easterly, William. 2003. "The Cartel of Good Intentions: The Problem of Bureaucracy in Foreign Aid." Journal of Policy Reform 5(4): 1-28.

Evans, Peter B., and James E. Rauch. 1999. "Bureaucracy and Growth: A Cross-National Analysis of the Effects of 'Weberian' State Structures on Economic Growth." American Sociological Review 64: 748-65.

Fallon, Peter R., and Luiz A. Pereira da Silva. 1994. "Recognizing Labor Market Constraints: Government-Donor Competition for Manpower in Mozambique." In D. L. Lindauer and Barbara Nunberg, eds., Rehabilitating Government: Pay and Employment Reform in Africa. Washington, D.C.: The World Bank.

Grossman, Herschel I. 1992). "Foreign aid and insurrection." Defense Economics 3: 27588.

Hardin, Russell. 1982. Collective Action. Baltimore, Md.: Johns Hopkins University Press.

Jepma, Catrinus J. 1991. The Tying of Aid. Paris: OECD Development Center.

Kanbur, Ravi, and Todd Sandler. 1999. The Future of Development Assistance: Common Pools and International Public Goods. ODC Policy Essay No. 25. Washington DC: Overseas Development Council.

Kaufmann, Dani, Aart Kraay, and Massimo Mastruzzi. 2003. “Governance Matters III: Governance Indicators for 1996-2002.” Policy Research Working Paper 3106. World Bank, Washington, D.C.

Keefer, Philip, and Stephen Knack. 1997. "Why Don't Poor Countries Catch Up? A Cross-Country Test of an Institutional Explanation.” Economic Inquiry 35(3): 590-602.

Klitgaard, Robert (1997). "Cleaning Up and Invigorating the Civil Service." Public Administration and Development 17: 487-509.

Knack, Stephen. 2003. Democracy, Governance and Growth. Ann Arbor: University of Michigan Press.

Knack, Stephen. 2001. "Aid Dependence and the Quality of Governance: Cross-Country Empirical Tests." Southern Economic Journal 68(2): 310-29.

Knack, Stephen, and Omar Azfar. 2003. "Trade Intensity, Country Size and Corruption." Economic of Governance 4(1): 1-18.

La Porta, Rafael, Florencio Lopez-de-Silanes, Andrei Shleifer, and Robert Vishny. 1999. "The quality of government." Journal of Law, Economics, and Organization 5(1): 222-79.

Lundborg, Per (1998). "Foreign aid and international support as a gift exchange." Economics and Politics 10(2): 127-41. 
Maren, Michael. 1997. The road to hell: The ravaging effects of foreign aid and international charity. New York: The Free Press.

Martens, Bertin, Uwe Mummert, Peter Murrell and Paul Seabright. 2002. The Institutional Economics of Foreign Aid. Cambridge, UK: Cambridge University Press.

Morss, Elliott R. 1984. "Institutional Destruction Resulting from Donor and Project Proliferation in Sub-Saharan African Countries." World Development 12(4): 46570.

Mosley, Paul, and Marion J. Eeckhout. 2000. "From Project Aid to Program Assistance." In F. Tarp, ed., Foreign Aid and Development: Lessons Learnt and Directions for the Future. London: Routledge.

OECD. 2003. Harmonizing Donor Practices for Effective Aid Delivery. Paris: OECD.

OECD. 2001. "Development Cooperation Review of the Netherlands." DAC Journal $1(2)$.

O'Connell, Stephen A., and Charles C. Soludo. 2001. "Aid Intensity in Africa." World Development 29(9): 1527-52.

Olson, Mancur. 1965. The Logic of Collective Action. Cambridge, Mass.: Harvard University Press.

PRS Group. 1998. International Country Risk Guide (vol. 19, no. 4, April). Syracuse, NY: IBC.

Swamy, Anand, Stephen Knack, Young Lee and Omar Azfar. 2001. "Gender and Corruption." Journal of Development Economics 64: 25-55.

Treisman, Daniel. 2000. "The causes of corruption: A cross-national study." Journal of Public Economics 76(3): 399-457.

UNDP. 2003. Human Development Report 2003. New York: Oxford University Press.

Van de Walle, Nicolas. 2001. African Economies and the Politics of Permanent Crisis. Cambridge: Cambridge University Press.

Van de Walle, Nicolas, and Timothy Johnston. 1996. Improving Aid to Africa. ODC Policy Essay No. 21. Washington DC: Overseas Development Council.

Whittington, Dale, and Craig Calhoun. 1988. "Who Really Wants Donor Coordination?" Development Policy Review 6: 295-309.

Wilson, L. S. 1993. "Kenyanization and African Capacity 'Shuffling'." Public Administration and Development 13: 489-99.

World Bank. 2003. World Development Report 2004: Making Services Work for Poor People. New York: Oxford University Press.

World Bank. 2000. Reforming Public Institutions and Strengthening Governance: A World Bank Strategy. Washington, D.C.: World Bank.

World Bank. 1998. Assessing aid: What works, what doesn't, and why. New York: Oxford University Press.

Wuyts, Marc. 1996. "Foreign Aid, Structural Adjustment, and Public Management: The Mozambican Experience." Development and Change 27: 717-49. 